\title{
THE EFFECTS OF A COMBINED OUTPUT AND INPUT-ORIENTED APPROACH IN TEACHING REPORTED SPEECH
}

\author{
ANNA MYSTKOWSKA-WIERTELAK \\ Zakład Filologii Angielskiej \\ UAM Poznań WPA Kalisz \\ mystkows@amu.edu.pl
}

\begin{abstract}
The author of the present study investigates the effects of output and input-oriented treatment on the acquisition of English reported speech, a complex phenomenon posing considerable difficulty even to more advanced learners of the language. The study focuses on two research questions:

1. Will there be any differences in how learners exposed to reception-oriented, production-oriented and a combined type instructional treatments interpret and produce sentences containing reported speech?

2. Is the effect durable, as measured on immediate and delayed post-tests?

The participants of the study are 74 first year students of the English philology who were divided into four groups: 3 treatment groups and a control one. The study results do not mirror those reported in the vast majority of relevant literature and points that although input manipulation appears to have more beneficial effect on the development of the interlanguage than the analysis of output, a combination of the two approaches turns out to be the most beneficial and economical.
\end{abstract}

\section{Introduction}

Regardless of their theoretical background most SLA researchers acknowledge the importance of input in second language learning. While comparing the most influential views on the role of input in the second language acquisition (Krashen, 1985; LarsenFreeman and Long, 1991; Ellis, 1994, Schwartz, 1993), Bill VanPatten points out that, despite considerable differences, all SLA models devote much attention to input and unanimously acknowledge that "meaning-bearing input is essential to second language acquisition"(1996:5). The inquiry into the role of input in language acquisition that stemmed from the research of child L1 processing (e.g. Slobin 1973) has grown into a substantial field of SLA studies and produced an abundance of research projects and, consequently, valuable insights into the nature of language processing. Considerations on the assignment of function to nouns, sentence parsing, the mechanisms governing linking of particular forms to their meaning and function led the researchers (Chaudron (1985), Sharwood Smith (1986), Gass (1997), and Carroll (1999, 2000), Lee, 1987; 
LoCoco, 1987) to the formulation of numerous hypotheses and, subsequently, offering of pedagogic applications.

\section{Review of literature}

The key concept that most of the models refer to is intake presented by Corder in 1967 and often called "the cornerstone of input-related research" (Sun, 2008:2):

The simple fact of presenting a certain linguistic form to a learner in the classroom does not necessarily qualify it for the status of input, for the reason that input is "what goes in" not what is available for going in, and we may reasonably suppose that it is the learner who controls this input, or more properly his intake (Corder, 1967: 165)

It needs to be noted that Corder's development changed the way input was perceived: it became obvious that it is not a solely external phenomenon but rather a kind of interface between the stimuli reaching the brain and the internal systems learners are equipped with (Sun:2). If not all the data learners are exposed to becomes absorbed, attempts to identify the conditions pertinent to the input-intake conversion became the central point of research. One of such efforts was the proposal by Bill VanPatten (1993, 1996, 2002, 2004) who put forward his own model of acquisition in which he devoted most attention to the initial processes in the course of which learners connect grammatical structures to their meaning and interpret the noun verb relations in a sentence. According to VanPatten not all of the language in the learner's environment becomes acquired due to the filtering mechanisms that allow only part of the information to become incorporated. The model proposed by Van Patten can be briefly summarized as a set of interrelated processes starting with the conversion of input into intake, then its accommodation and restructuring which result in partial or complete incorporation of the newly registered data into the developing system (IL), which may bring about some kind of its restructuring. In the final stage the incorporated language may become available for the learner as output or production.

Only one of the above processes, input processing, assumes the focal position in the model developed by VanPatten (1996). He claims that the primary concern of a learner is the extraction of meaning from input. Thus, some important features can be left unattended if they are not salient enough for the attentional resources to be detected. If acquisition is to take place, learners must 'notice' things in the input. However, noticing is constrained by working memory limitations concerning the sheer amount of information they can hold and process during real time processing of sentences during comprehension (2004:7).

The basics tenets of Van Patten's model are comprised in the repeatedly amended and verified set of principles - a collection of default strategies and mechanisms employed by learners while processing new information. These strategies, oriented on meaning-extraction, promote comprehension but hinder the creation or revision of mental structures. Thus, as Van Patten proposes, learners need to be assisted in the abandonment of these and encouraged to attend to the specific form that is to be acquired. 
P 1. The Primacy of Meaning Principle. Learners process input for meaning before they process it for form.

P 1a. The Primacy of Content Words. Learners process content words in the input before anything else.

P 1b. The Lexical Preference Principle. Learners will tend to rely on lexical items as opposed to grammatical form to get meaning when both encode the same semantic information.

$\mathrm{P}$ 1c. The Preference of Non-redundancy Principle. Learners are more likely to process non-redundant meaningful grammatical form before they process redundant meaningful forms.

P 1d. The Meaning-Before-Nonmeaning Principle. Learners are more likely to process meaningful grammatical forms before nonmeaningful forms irrespective of redundancy.

$\mathrm{P}$ 1e. The Availability of resources Principle. For learners to process either redundant meaningful grammatical forms or nonmeaningful forms, the processing of overall sentential meaning must not drain available processing resources.

P 1f. The Sentence Location Principle. Learners tend to process items in sentence initial position before those in final position and those in medial position (2004:14).

P 2. The First Noun Principle. Learners tend to process the first noun or pronoun they encounter in a sentence as the subject/agent.

P 2a. The Lexical Semantics Principle. Learners may rely on lexical semantics, where possible, instead of word order to interpret sentences.

P 2b. The Event Probabilities Principle. Learners may rely on event probabilities, where possible, instead of word order to interpret sentences.

P2c. The Contextual Constraint Principle. Learners may rely less on the First Noun Principle if preceding context constraints the possible interpretation of a clause or sentence

(2004:18).

A practical application of the model is "processing instruction"(PI), whose aim is to help learners derive richer intake from input by having them engaged in structured input activities that push them away from the processing strategies they normally use to make form-meaning connections. (Wong: 2004) With the emphasis on learners input rather than output, PI offers an opportunity to analyze the meaning-form relationship without being required to produce the target structure. Learners first need to be provided with explicit information about the targeted form accompanied by information about the relevant processing strategies followed by structured input (SI) activities. It is important to point out that SI activities cannot be equated with just any kind of input-based activity. First of all, the activity must force the learners to abandon the inefficient strategies they usually employ, that's why the problem must be identified before the development of the activities can start. There are two types of SI activities: referential and affective ones. Referential SI activities require learners to pay attention to form in order to get meaning and have a right or wrong answer so the instructor can check whether or not the learner has actually made the proper form-meaning connection. Affective SI activities don't have good or wrong answers, they require learners to express an opinion, belief or some other affective response as they are engaged in processing information about the real world. 


\section{Research evidence contrasting TI, PI and MOI}

Since the first publication of the exposition of Bill VanPatten's ideas on grammar instruction (VanPatten, 1993), the concept of Processing Instruction has been extensively researched by numerous scholars and the founder himself (Lee and VanPatten 1995, 2003; VanPatten 1996, 2003, 2004a) and abundant empirical investigations conducted so far seem to demonstrate the beneficial and lasting effects of VanPatten's approach to grammar instruction on second language development. There are two main types of comparison conducted to date: the effects of processing instruction was either collated with Traditional Instruction or Meaning-based Output Instruction. The term Traditional Instruction corresponds to the treatment in the course of which learners are provided with explicit information about a form or structure followed by a series of controlled output exercises proceeding from mechanical drills to meaningful and communicative activities. Engaging learners in the production of the targeted structure is viewed as the utmost way of helping them remember it. In an attempt to resolve the possible misunderstanding surrounding the concept of TI, VanPatten (2002) cites Paulston's description of a typical language lesson in most of second/foreign language classrooms: "[A] grammar lesson should consist of grammatical rules that explain the particularities of the structural pattern to be learned plus a series of drills form mechanical level to a communicative in order to give students optimal practice in language production" (1976: 4). Table 1 presents an overview of the effects of PI juxtaposed to those of TI that concern different processing problems in different languages. In the studies presented the researchers measure language development using two assessment tasks, one that necessitates utterance interpretation and the other production of the investigated form.

\begin{tabular}{|c|c|c|c|}
\hline Study & Linguistic Item & Interpretation results & Production Results \\
\hline Van Patten & Spanish object & $\mathrm{PI}>(\mathrm{TI}=\mathrm{C})$ & $(\mathrm{PI}=\mathrm{TI})>\mathrm{C}$ \\
\hline Cadierno 1993 & & & \\
\hline Cadierno 1995 & $\begin{array}{l}\text { Spanish preterite } \\
\text { tense }\end{array}$ & $\mathrm{PI}>(\mathrm{TI}=\mathrm{C})$ & $(\mathrm{PI}=\mathrm{TI})>\mathrm{C}$ \\
\hline Benati 2001 & Italian future tense & $\mathrm{PI}>\mathrm{TI}>\mathrm{C}$ & $(\mathrm{PI}=\mathrm{TI})>\mathrm{C}$ \\
\hline Cheng 2002 & Spanish copula & $\mathrm{PI}>(\mathrm{TI}=\mathrm{C})$ & $(\mathrm{PI}=\mathrm{TI})>\mathrm{C}$ \\
\hline $\begin{array}{l}\text { VanPatten \&Wong } \\
2004\end{array}$ & French causative & $\mathrm{PI}>\mathrm{TI}>\mathrm{C}$ & $(\mathrm{PI}=\mathrm{TI})>\mathrm{C}$ \\
\hline Cheng 2004 & Spanish copula & - & $(\mathrm{PI}=\mathrm{TI})>\mathrm{C}$ \\
\hline Benati 2005 & English simple past & $\mathrm{PI}>\mathrm{TI}=\mathrm{MOI}$ & $\mathrm{PI}=\mathrm{TI}=\mathrm{MOI}$ \\
\hline Lee \& Benati 2007 & Japanese past tense & $\mathrm{PI}>\mathrm{TI}$ & $\mathrm{PI}=\mathrm{TI}$ \\
\hline Lee \& Benati 2007 & $\begin{array}{l}\text { Japanese } \\
\text { affirmative } \\
\text { negative present } \\
\text { tense }\end{array}$ & $\mathrm{PI}>\mathrm{TI}$ & $\mathrm{PI}=\mathrm{TI}$ \\
\hline $\begin{array}{lr}\text { MOI= } & \text { Meaning- } \\
\text { based } & \text { Output } \\
\text { Instruction } & \end{array}$ & $\begin{array}{l}\mathrm{TI}=\quad \text { Traditional } \\
\text { Instruction }\end{array}$ & $\mathrm{C}=$ Control group & $\begin{array}{l}\mathrm{PI}=\text { Processing } \\
\text { Instruction }\end{array}$ \\
\hline
\end{tabular}

Table 1: Overview of the immediate effects of PI compared to those of TI (adapted from Lee \& Benati 2007:140-141) 
As can be seen learners exposed to PI outperform traditionally instructed learners on interpretation tasks no matter which language and processing problem is investigated. The results of the production measure indicate that PI $=\mathrm{TI}$, despite the fact that PI subjects were never required to produce the addressed form. Moreover, the delayed posttest results show another important advantage: the effects of the PI treatment remained for three or four weeks after the instruction was provided (Lee \& Benati 2007:41).

The consistent prevalence of PI over TI shown by VanPatten and Cadierno (1993) and Cadierno (1995) inspired some questions concerning the nature of the output practices the TI groups were engaged in. Moreover, it was pointed out that the PI and TI groups received different types of explicit information about the targeted structure: while the PI group learned about the structure and the processing strategies, the TI were instructed about the structure only. In response to the above queries researchers decided to compare PI to MOI - meaning-based output instruction and provide all treatment groups with the same explicit information.

TI and MOI have much in common, they both consist of explicit information about a grammatical form followed by production activities. The activities that follow TI are mostly mechanical drills such as substitution and transformation drills for which there is only one correct answer (Lee and VanPatten, 2003:121). The production practices employed by the MOI treatment are by no means mechanical - first and foremost they are communicative and interactive (Lee and VanPatten, 2003:173-177). What is more, they cannot be classified as purely output-oriented practice since, as specified by Farley 2001a: 76 “ (...) when learners responded during the follow-up phase of each activity their utterances served as incidental input for their classmates: the incidentally focused input made the subjunctive more salient than it would be with raw, unfocused input." Table 2 presents a chronological overview of the studies comparing the effects of PI and MOI. Again, as in the studies comparing PI to TI, the linguistic gain is compared in an interpretation and a production measure.

\begin{tabular}{|c|c|c|c|}
\hline Study & Linguistic Item & Interpretation & Production \\
\hline Farley 2001a & $\begin{array}{l}\text { Spanish } \\
\text { subjunctive }\end{array}$ & $\mathrm{PI}>\mathrm{MOI}$ & $\mathrm{PI}=\mathrm{MOI}$ \\
\hline Farley $2001 b$ & $\begin{array}{l}\text { Spanish } \\
\text { subjunctive }\end{array}$ & $\mathrm{PI}=\mathrm{MOI}$ & $\mathrm{PI}=\mathrm{MOI}$ \\
\hline Benati 2005 & English simple past & $\mathrm{PI}>\mathrm{MOI}=\mathrm{TI}$ & $\mathrm{PI}=\mathrm{MOI}=\mathrm{TI}$ \\
\hline Lee \& Benati 2007 & Italian subjunctive & $\mathrm{PI}>\mathrm{MOI}$ & $\mathrm{PI}=\mathrm{MOI}$ \\
\hline Lee \& Benati 2007 & French subjunctive & $\mathrm{PI}>\mathrm{MOI}$ & $\mathrm{PI}=\mathrm{MOI}$ \\
\hline $\begin{array}{l}\mathrm{PI}=\text { Processing } \\
\text { Instruction }\end{array}$ & $\begin{array}{l}\mathrm{TI}=\text { Traditional } \\
\text { Instruction }\end{array}$ & $\begin{array}{lr}\text { MOI = } & \text { Meaning- } \\
\text { based } & \text { Output } \\
\text { Instruction } & \end{array}$ & \\
\hline
\end{tabular}

Table 2: Overview of the immediate effects of PI compared to those of MOI (adapted from Lee \& Benati 2007:142)

Farley (2001a, 2001b) conducted the experiment comparing the effects of PI and MOI on the acquisition of the Spanish subjunctive of doubt. The results obtained in the study 
indicate that both the IP and MOI groups improved on the interpretation and production tasks.

Benati refers to his own and that of Gely's (2005) experiment comparing the effects of MOI, PI and TI. Benati investigated the acquisition of the English simple past tense resulting from the application of the three modes of instruction. As expected, the PI group outperformed the other groups on the interpretation task and the statistical analysis of the results revealed that all three treatment groups equally benefited from instruction on the production task. Benati concluded that not only did PI improve the subjects ability to interpret the target feature but also the way they produced language. Gely's experiment concerned the acquisition of the French imperfect tense that was the effect of the application of either PI or MOI. The PI group performed better than the MOI on interpretation and equalled it on production. Although Benati's and Gely's findings only partially coincide with those of Farley, it can be inferred that PI exceeds output-oriented instruction, no matter whether mechanical or meaning-based (Lee and Benati 2007: 105).

\section{Motivation for the present study}

The results of the studies briefly revised so far show the advantage of reception-oriented instruction over the traditional approach. The author of the present study aimed to investigate the effects of the treatment that would comprise both types of treatment output and input-oriented on the acquisition of English reported speech which is a complex phenomenon posing considerable difficulty even to more advanced learners of the language. The problems referring to the use of reported speech that learners encounter are manifold: the proper use of tenses, word order, use of time words and pronouns together with the appropriate interpretation of modal verbs used in the actual speech. Since some of the messages can be interpreted using certain report verbs, students need to know the verb pattern a given verb represents often together with the preposition that accompanies it. According to Principle 1b. The Lexical Preference Principle, learners' first look for the message in the input before they look for the grammatical ways through which this message is encoded. Learners are more likely to rely on lexical items as opposed to grammatical form to get meaning when both encode the same semantic information. Another processing problem in English reported speech is how to get learners to process the formal linguistic features when the semantic notions are conveyed lexically elsewhere in the sentence. The lexemes render the formal features redundant and as stated in VanPatten's (2004b) P1c. The preference for the Nonredundancy Principle, learners tend to process non-redundant meaningful grammatical form before they process redundant meaningful forms. What is more, learners who have mastered the rules regulating the use of tense forms not infrequently disregard the changes concerning adverbs and time words, which seems to conform with VanPatten's Sentence Location Principle stating that learners tend to process elements in the initial position before elements in the final position. 


\section{Research questions}

The present study is guided by the following research questions:

1. Will there be any differences in how learners exposed to reception-oriented, production-oriented and a combined type instructional treatments interpret and produce sentences containing Reported Speech?

2. Is the effect durable, as measured on immediate and delayed posttests?

\section{Design}

\subsection{Participants}

The participants of the study were 74 first year students of the English philology who were divided into four groups: 3 treatment groups and a control one. The three experimental groups received a varied type of instruction reception-oriented, productionoriented and a combination of the two on two consecutive days. Only tests were given to the control group. A pretest/post test and a delayed posttest approach was adopted to examine both short and long term effects of the three instructional treatments. The pretests were administered immediately before the beginning of the treatment and posttests 1 immediately after the end of the treatment. The delayed postest was performed 4 weeks after the first posttest. Another delayed posttest is still to be performed 6 months following the instruction. That is why four different versions of the test were devised and randomly assigned to the subjects during the pretest procedure. Although much effort was put into ensuring that the four versions are equivalent in difficulty, there was still no guarantee they were properly balanced, and, therefore the following testing scheme was adopted. For the pretest one fourth of the subjects completed version $\mathrm{A}$, one fourth version $\mathrm{B}$, one fourth version $\mathrm{C}$, and one fourth version D. On the following tests the versions were shuffled so that each of the students wrote one and the same version only once. The test consisted of two parts - a sentence interpretation task and a production measure: paraphrasing.

\subsection{Instructional treatments}

Three separate packets of materials were designed, one for the Input-based, one for the Output-based and one for the Combined treatment group. Instructional materials were balanced in all respects (e.g. vocabulary, total number of activities, number of exemplars). Popular grammar book and coursebook materials were specially adapted to match each of the researched approaches. A Power Point presentation was used during the explicit instruction stage to make sure that each group was exposed to an equal number of example sentences and the same problems were discussed in exactly the same order. The treatment which took place on two consecutive days lasted from 3 to 4 hours. The difference in the time span needed to accomplish all the tasks designed resulted from the fact that each of the approaches necessitated different time allocation for one 
and the same task. While a simple rewriting activity took $5 \mathrm{~min}$. in the output group, a discussion concerning the consequences of somebody's decisions lasted much longer. The otherwise balanced treatment materials differed fundamentally in one respect - each set required a different type of response from the subjects. Moreover, the input group were informed about the existence and application of the default strategies - the Principles that needed do be abandoned if acquisition was to be more effective. The Input group were involved in Structured input activities and interpretation tasks (cf. Ellis 1995) that did not require the production of the target form, whereas the Output group were engaged in the activities (mostly mechanical in nature but also meaning-oriented) that required the production of the structure in question. The materials prepared for the third group comprise exactly the same number of activities and tasks as in the previous groups, however, each of the tasks required first processing of the input in the course of SI activities followed by partly mechanical production of the targeted structure. The underneath examples present the way one and the same activity was adapted for the use in the three treatment groups. The task comes from a popular grammar handbook "Grammar Sense" by Susan Kersner Bland. While the input group members got engaged in an affective structured activity requiring their appraisal of the advice a fictitious character received from her friends and relatives, the output group simply rewrote the actual speech utterances into reported speech. They were also invited to write what they would suggest. Their answers were read and then reported by fellow students. The task of the Combined group was to express their opinion about the first two pieces of advice and then rewrite the remaining actual speech sentences. Apart form rewriting the production stage of the task required the presentation of each student's advice that was later reported in class. The remaining teaching materials used in the experiment were tackled similarly (see Appendix A).

\section{Results}

\subsection{The reception data}

Because of the fact that the two tests used for assessment differed in the number of items they contained, all scores were converted to percentages in the statistical analyses. First, an average score from the pretest scores was calculated. It turned out that the average pretest results obtained by the four groups were quite similar: $70 \%$ for the input group $63,5 \%$ in the output, $74,1 \%$ in the combined and $68,7 \%$ in the control group. There were no significant differences between the scores and that is why the differences that were revealed in the post test procedure can be attributed to the type of treatment that was administered to each of the experimental groups. Figure 1 below shows the percentages of correct responses obtained by the learners on the reception tests. 


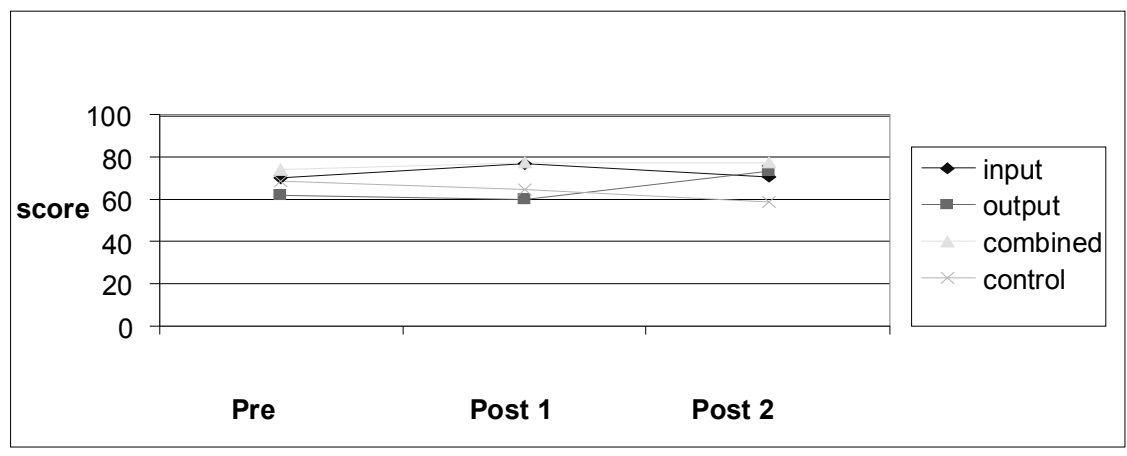

Figure 1: Means for reception task (pretest, immediate posttest and delayed posttest) for reported speech.

To explore the main effect for the type of instruction and the effect of time a series of paired means comparisons - two-tailed t tests were performed. The results are presented in Table 3 and 4. The comparisons of the scores obtained on post test 1 revealed that both the Input and Combined groups benefited from the instruction they received $76,7 \%$ and $77,6 \%$ respectively. Interestingly, the output group performed slightly worse on the immediate posttest than on the pretest but outperformed this result on the delayed postest nearing the results of the other experimental groups. This impressive increase can be attributed to the fact that the treatment they underwent made them more sensitive to the targeted structure in the environment and improved its detection. The immediate posttest results indicated a significant advantage of the Input group over the Output one and the Combined group outperformed both the Output and Control. The scores obtained in the course of the delayed posttest measure clearly indicate that the IP procedure did not suffice to produce durable effects. Paradoxically, the Output and the Combined groups that spent less time on reception practice retained the benefits of instruction.

\begin{tabular}{|c|c|c|c|c|}
\hline group & $\begin{array}{l}\text { Pretest } \\
\text { Mean }\end{array}$ & $\begin{array}{ll}\text { Posttest } & 1 \\
\text { Mean } & \end{array}$ & $\begin{array}{l}\text { Posttest } 2 \\
\text { Mean }\end{array}$ & $\begin{array}{l}\text { 2-tailed paired samples t- } \\
\text { test }\end{array}$ \\
\hline Input & 70,00 & 76,7 & 70,7 & $\begin{array}{l}\text { Pre }- \text { Post } 1 \mathrm{t}=1,35 \\
\mathrm{p}=0,20 \\
\text { Post } 1-\text { Post } 2 \mathrm{t}=0,84 \\
\mathrm{p}=0,42 \\
\text { Pre }- \text { Post } 2 \mathrm{t}=0,06 \\
\mathrm{p}=0,93\end{array}$ \\
\hline Output & 63,5 & 60,0 & 73,1 & $\begin{array}{l}\text { Pre }- \text { Post } 1 \mathrm{t}=0,30 \\
\mathrm{p}=0,77 \\
\text { Post } 1-\text { Post } 2 \mathrm{t}=0,30 \\
\mathrm{p}=0,77 \\
\text { Pre }- \text { Post } 2 \mathrm{t}=2,35 \\
\mathrm{p}=0,03\end{array}$ \\
\hline
\end{tabular}




\begin{tabular}{|c|c|c|c|c|}
\hline group & $\begin{array}{l}\text { Pretest } \\
\text { Mean }\end{array}$ & $\begin{array}{l}\text { Posttest } 1 \\
\text { Mean }\end{array}$ & $\begin{array}{l}\text { Posttest } 2 \\
\text { Mean }\end{array}$ & $\begin{array}{l}\text { 2-tailed paired samples t- } \\
\text { test }\end{array}$ \\
\hline Combined & 74,1 & 77,6 & 77,6 & $\begin{array}{l}\text { Pre }- \text { Post } 1 \mathrm{t}=0,59 \\
\mathrm{p}=0,56 \\
\text { Post } 1-\text { Post } 2 \mathrm{t}=0 \\
\mathrm{p}=1 \\
\text { Pre }- \text { Post } 2 \mathrm{t}=0,65 \\
\mathrm{p}=0,52\end{array}$ \\
\hline Control & 68,7 & 64,7 & 58,7 & $\begin{array}{l}\text { Pre }- \text { Post } 1 \mathrm{t}=0,56 \\
\mathrm{p}=0,56 \\
\text { Post } 1-\text { Post } 2 \mathrm{t}=0,85 \\
\mathrm{p}=0,42 \\
\text { Pre }- \text { Post } 2 \mathrm{t}=1,46 \\
\mathrm{p}=0,16\end{array}$ \\
\hline
\end{tabular}

Table 3. Accuracy percentages for the use of reported speech on the reception test (significant values are in bold).

\begin{tabular}{|c|c|c|}
\hline Pretest & Posttest 1 & Posttest 2 \\
\hline & $\begin{array}{l}\text { Input }>\text { Output } \\
\text { Combined }>\text { Output } \\
\text { Combined }>\text { Control }\end{array}$ & $\begin{array}{l}\text { Output }>\text { Control } \\
\text { Combined } \\
\text { Control }\end{array}$ \\
\hline
\end{tabular}

Table 4: Comparison of the results obtained on reception in the three experimental and a control group. Only statistically significant differences provided.

\subsection{The production data}

The mean scores for all the groups were calculated and as shown in Figure 2 the results corresponding to the production of the form in question improved. Similarly, as in the case of the reception data, two-tailed t tests were performed to explore the effects of the three designed treatments on the ability to produce the targeted form. The comparisons revealed the nature of the main effect for Time as shown on the immediate posttest and the delayed posttest. The pretest procedure disclosed that the three treatment groups did not differ from each other with reference to the ability to produce Reported speech, however, the control group turned out to be less proficient than the others and the difference was statistically significant between the Control and the Input group. This low level of proficiency with respect to reported speech persisted throughout the whole procedure. Nevertheless, the delayed posttest result for the Control group showed a 
slight increase that might have resulted from the practice effect generated in the course of test taking. All the experimental groups scored better than the Control group and important differences were observed between the experimental groups. While any significant changes concerning production in the Input group were not detected and the Output group improved only slightly, the Combined group outperformed all the others. The difference was statistically significant for the Control and Output group. The advantage over the Input group was also observed, however, it was not statistically significant. The same regularity was present in the delayed posttest procedure. The growing tendency was retained in the three treatment groups with a slightly more conspicuous gain in the output group. Table 6 shows the comparison of effects of the three types on treatment and the control group. The results that were statistically significant are included in the table.

\begin{tabular}{|c|c|c|c|c|}
\hline group & $\begin{array}{l}\text { Pretest } \\
\text { Mean }\end{array}$ & $\begin{array}{ll}\text { Posttest } & 1 \\
\text { Mean } & \end{array}$ & $\begin{array}{ll}\text { Posttest } & 2 \\
\text { Mean } & \end{array}$ & $\begin{array}{l}\text { 2-tailed paired samples t- } \\
\text { test }\end{array}$ \\
\hline Input & 65,11 & 65,11 & 66,89 & $\begin{array}{l}\text { Pre }- \text { Post } 1 \mathrm{t}=0 \\
\mathrm{p}=1,00 \\
\text { Post } 1-\text { Post } 2 \mathrm{t}=0,27 \\
\mathrm{p}=0,74 \\
\text { Pre }- \text { Post } 2 \mathrm{t}=0,24 \\
\mathrm{p}=0,81\end{array}$ \\
\hline Output & 50,62 & 53,33 & 58,96 & $\begin{array}{l}\text { Pre }- \text { Post } 1 \mathrm{t}=0,47 \\
\mathrm{p}=0,64 \\
\text { Post } 1-\text { Post } 2 \mathrm{t}=0,86 \\
\mathrm{p}=0,41 \\
\text { Pre }- \text { Post } 2 \mathrm{t}=1,56 \\
\mathrm{p}=0,13\end{array}$ \\
\hline Combined & 61,57 & 80,39 & 80,98 & $\begin{array}{l}\text { Pre }- \text { Post } 1 \mathrm{t}=3,96 \\
\mathbf{p}=\mathbf{0 , 0 0 1} \\
\text { Post } 1-\text { Post } 2 \mathrm{t}=0,14 \\
\mathrm{p}=0,89 \\
\text { Pre }- \text { Post } 2 \mathrm{t}=4,89 \\
\mathbf{p}=\mathbf{0 , 0 0 2}\end{array}$ \\
\hline Control & 40,00 & 60,00 & 42,44 & $\begin{array}{l}\text { Pre }- \text { Post } 1 \mathrm{t}=0,36 \\
\mathrm{p}=0,7 \\
\text { Post } 1-\text { Post } 2 \mathrm{t}=1,01 \\
\mathrm{p}=0,33 \\
\text { Pre }- \text { Post } 2 \mathrm{t}=0,34 \\
\mathrm{p}=0,74\end{array}$ \\
\hline
\end{tabular}

Table 5: Accuracy percentages for the use of inversion on the production test (significant values are in bold). 


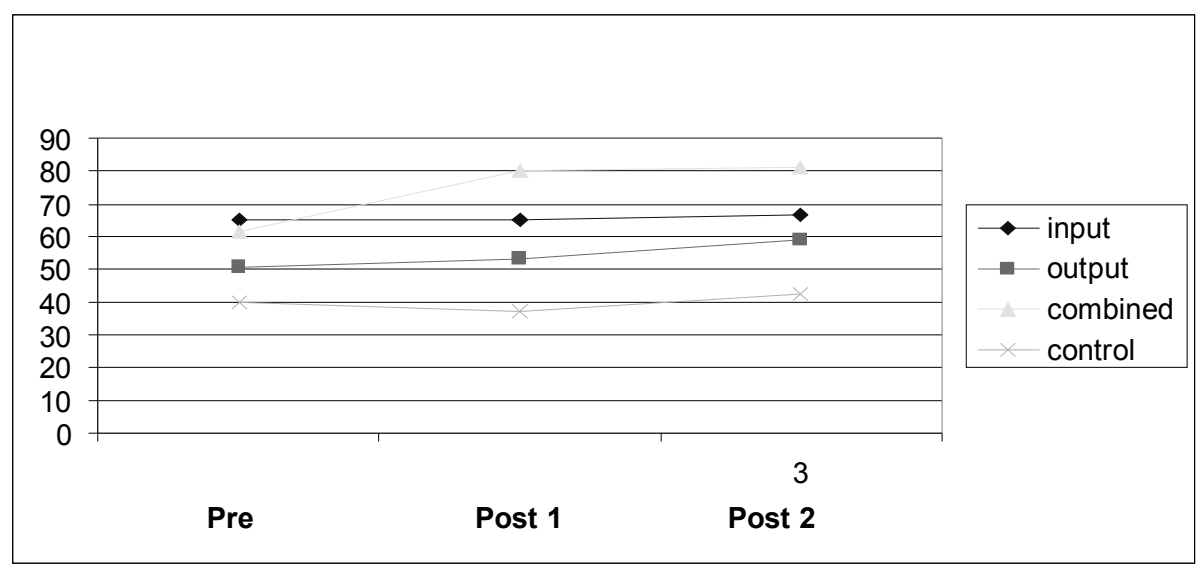

Figure 2: Means for production task (pretest, immediate posttest and delayed posttest) for reported speech.

\begin{tabular}{|l|l|l|}
\hline Pretest & Posttest 1 & Posttest 2 \\
\hline Input $>$ Control & Input $>$ Control & Input $>$ Control \\
& Output $>$ Control \\
& Combined $>$ Output & Combined $>$ Control \\
& Combined $>$ Control & \\
\hline
\end{tabular}

Table 6: Comparison of the results obtained on the production measure in the three experimental and a control group. Only statistically significant differences provided.

\section{Conclusions}

The results obtained in the above investigation do not mirror those of the vast majority of PI research (cf. Table 1 and Table 2). It can be argued that teaching that focuses learners' attention on the structure without requiring to produce it better complies with natural processes involved in learning a foreign language. However, it should be noted that all three types of instruction affected the learners' performance. The students in all experimental groups appeared to benefit from the pedagogic intervention, although the extent of improvement depended also on the learners' overall proficiency level as well as the type of tasks they were required to engage. An obvious weakness of the study is not taking into account individual differences. An attempt to establish how many of the students actually benefited from a given type of treatment and whether the gain was maintained over time would have helped to interpret the collected data more fully. Although input manipulation appears to have more beneficial effect on the development 
of the interlanguage than the analysis of output, a combination of the two approaches turned out to be the most beneficial and economical. Approximately the same time span was allocated to the treatments but the most conspicuous increase was observed in the Combined group. It seems legitimate to say that a combination of the two approaches, reception- and production-based, constitutes the most advantageous solution to the problem of grammar instruction in the language classroom.

\section{References}

Benati, A. 2001. A comparative study of the effects of processing instruction and outputbased instruction on the acquisition of the Italian future tense. Language Teaching Research 5: 95-127.

Benati, A. 2005. The effect of processing instruction, traditional instruction and meaning-output instruction on the acquisition of the English past simple tense. Language Teaching Research 9: 67-93.

Blend, S.K. 2003. Grammar sense 3. Oxford: OUP.

Cadierno, T. 1995. Formal instruction from a processing perspective: An investigation into the Spanish past tense. The Modern Language Journal 79: 179-93.

Carroll, S. 1999. Putting 'input' in its proper place. Second Language Research 15: 337388.

Carroll, S. 2000. Input and evidence: The raw material of second language acquisition. Philadelphia: John Benjamins.

Chaudron, C. 1985. Intake: On methods and models for discovering learners' processing of input. Studies in Second Language Acquisition 7: 1-14.

Cheng, A. 2002. The effects of processing instruction on the acquisition of ser and estar. Hispania 85: 308- 323.

Cheng, A. 2004. Processing instruction and Spanish ser and estar: Forms with semanticaspectual value. In B. VanPatten, (ed.) Processing instruction. Mahwah, NJ: Lawrence Erlbaum Associates: 119-142.

Corder, S. P. 1967. The significance of learners' errors. IRAL 5: 161-170.

Ellis, R. 1994. The study of second language acquisition. Oxford: Oxford University Press.

Farley, A. 2001a. The effects of processing instruction and meaning-based output instruction. Spanish Applied Linguistics 5: 57-94.

Farley, A. 2001b. Authentic processing instruction and the Spanish subjunctive. Hispania 84: 289-299.

Gass, S. M. 1997. Input, interaction, and the second language learner. Mahwah, NJ: Lawrence Elrbaum.

Gass, S. and C. Madden,. (eds). 1985. Input in second language acquisition. Rowley, MA: Newbury House.

Gely, A. 2005. Output-Based Instruction versus Processing Instruction on the Acquisition of the French imperfect tense. Unpublished Master's thesis, University of Greenwich, London.

Krashen, S. 1985. The input hypothesis. London: Longman. 
Larsen-Freeman, D. and M.H. Long. 1991. An introduction to second language acquisition research. London: Longman.

Lee, J. 1987. Comprehending the Spanish subjunctive: An information processing perspective. Modern Language Journal 71: 50-57.

Lee, J. and A.G Benati,. 2007. Delivering processing instruction in classrooms and in virtual contexts. Research and practice. London: Equinox.

Lee, J. and B.Van Patten. 1995. Making communicative language teaching happen. New York: McGraw-Hill.

Lee, J., Van Patten, B. 2003. Making communicative language teaching happen, $2^{\text {nd }}$ ed. New York: McGraw-Hill.

LoCoco, V. 1987. Learner comprehension of oral and written sentences. In B. Van Patten, T.R. Dvorak and J. Lee (eds.), Foreign language learning: A research perspective. Cambridge, MA: Newbury House.

Paulston, C. B. 1976. Pronouns of Address in Swedish: Social class Semantics and a Changing System, Language in Society 5(3): 359-386.

Schwarts, B. 1993. On explicit and negative data affecting and effecting competence and linguistic behavior. Studies in Second Language Acquisition 15: 147-164.

Sharwood-Smith, M. 1986. Comprehension vs. acquisition: Two ways of processing input. Applied Linguistics 7: 239-256.

Slobin, D. 1973. Cognitive prerequisites for the development of grammar. In: C.Ferguson D., Slobin (eds.), Studies of child language development. NewYork: Holt, Rinehart, Winston.

Sun, Y.A. 2008. Input Processing in Second Language Acquisition: A Discussion of Four Input Processing Models. In: Teachers College, Columbia University, Working Papers in TESOL \& Applied Linguistics 8/1. 1-10.

VanPatten, B. 1996. Input processing and grammar instruction. Norwood, NJ: Albex Publishing Corporation.

VanPatten, B. 2002. Processing instruction: An update. Language Learning 52: 755-803.

VanPatten, B. (ed.). 2004a. Processing instruction. Mahwah, NJ: Lawrence Erlbaum Associates.

VanPatten, B.(ed.). 2004b. Input processing in second language acquisition. In B.VanPatten (ed.) Processing instruction. Mahwah, NJ: Lawrence Erlbaum Associates. 5-31.

VanPatten, B., Cadierno, T. 1993. "Explicit instruction and input processing". Studies in Second Language Acquisition 15. 225-243.

VanPatten, B. and W. Wong. 2004. Processing instruction and the French causative: Another replication. In B. VanPatten (ed.) Processing instruction. Mahwah, NJ: Lawrence Erlbaum Associates. 97-118.

Wong, W. 2004. The nature of processing instruction. In B.VanPatten (ed.) Processing instruction. Mahwah, NJ: Lawrence Erlbaum Associates. 33-63. 


\section{APPENDIX A}

\section{INPUT}

\section{What do you think?}

Maria is a 30-year-old elementary school teacher. She is thinking....

Say what you think about the advice Maria gets from her family and friends. If you were Maria, which of the pieces of advice would appeal to you the most:

1. Maria's friend told her not to quit her job until she knows what she wants to do. She also recommended that she go to an employment agency.

2. Her husband suggested that she should think about getting a degree.

He also advised her to find out about different types of graduate programmes.

3. Her grandmother proposed she quit her job and have a baby. She also said that she should try to teach part-time instead of full-time.

4. Her father insisted she not quit but just take a leave of absence for a year. He also advised her to ask for a rise before she does anything else.

5. Her aunt suggested she ask to teach a different grade next year. She also said that she should do whatever makes her happy.

\section{OUTPUT}

Maria is a 30-year-old elementary school teacher. She is thinking....

Rewrite the sentences and say what you would suggest:

1. Maria's friend: "Quit your job until you know what you want to do.

Go to an employment agency."

Her friend told her to

2. Husband: "Think about getting a degree. Find out about different types of graduate programmes.

Her husband suggested.

3. Grandma: "Quit your job and have a baby! Try to teach part-time instead of full-time."

Her grandmother proposed.

4. Her father: "Do not quit. Just take a leave of absence for a year. Ask for a rise before you do anything else."

Her father insisted

5. Her aunt: "Ask to teach a different grade next year. Do whatever makes you happy."

Her aunt suggested

\section{COMBINED}

Maria is a 30-year-old elementary school teacher. She is thinking.... Say what you think about the advice Maria gets from her family and friends:

1. Maria's friend told her not to quit her job until she knows what she wants to do. 
She also recommended that she go to an employment agency.

2. Her husband suggested that she should think about getting a degree.

He also advised her to find out about different types of graduate programmes.

\section{Report the advice Maria gets from her relatives. What would you suggest?}

3. Grandma: "Quit your job and have a baby! Try to teach part-time instead of full-time."

Her grandmother proposed

4. Her father: "Do not quit. Just take a leave of absence for a year. Ask for a rise before you do anything else."

Her father insisted

5. Her aunt: "Ask to teach a different grade next year. Do whatever makes you happy."

Her aunt suggested

Adapted from: Bland, S.K. 2003: 405 